\title{
Grammar Translation Method and Discovery Learning to Learn Tenses: Which is Better for Indonesian Students?
}

\author{
Juhaeni M.Pd.I \\ English Education Department \\ UIN Sunan Ampel \\ Surabaya, Indonesia \\ Nikmatul Jazilah \\ English Education Department \\ UIN Sunan Ampel \\ Surabaya, Indonesia
}

\begin{abstract}
Learning tenses is challenging for Indonesian students in learning English. Therefore, an appropriate teaching strategyis needed to help students easily understand in learning about tenses. This research described the method for teaching tenses namely Grammar Translation Method (GTM) and Discovery Learning. Previously a lot of teachers used Grammar Translation Method and nowadays, the regulation from government asked schools to use Discovery Learning as method in teaching and learning process. The purposes of this research are to explain and elaborate clearly about the principles of these two methods. The principles includecharacteristics in teaching-learning process, the goals of the teaching, the roles of the teacher in the process of learning, and the last is nature of interaction between teacher and students in the class.
\end{abstract}

Keywords: EFL, learning resources, materials

\section{INTRODUCTION}

For EFL Learners in Indonesia, learning tenses had become the most intricate English skill that demotivates students until they want to drop from the course. The challenge happens for students who learn English as their second language when they have to memorize $r$ the rules of grammar especially tenses. Tenses are the relationship between the form of verb and the time of the actions or sentences describes (Richards and Schmidt, 2010). There are sixteen forms of tenses that showing events happened in the past, present, and future.Moreover, this form must be used based on the time of the event. The purpose is to know when the activity actually took place. In this case, Indonesian students do not foundsuch kind of principle in their first language, Bahasa. Often, they get confused about why the verbs or sentences must be changed if the time of the event is different.

There are many methods that have been applied in teaching grammar yet. The oldest method used by teacher to teach

\author{
Layni Zuhrotin Isnaini \\ English Education Department \\ UIN Sunan Ampel \\ SUrabaya, Indonesia \\ Khoiru Fadilah Hidayatu R. \\ English Education Department \\ UIN Sunan Ampel \\ Surabaya, Indonesia
}

grammar until now is Grammar Translation Method. This method requires students to translate whole text and memorize many grammatical rules and has purpose to help the students read and understand with foreign language literature. Another purpose of GTMis to enable the students to reach the skill of translation and considered as the most important factor to be successful in language learning (Larsen-Freeman and Anderson,2011). According to Prator and Celce-Murcia (1979:3) listed the major characteristic of Grammar Translation Method, they are (1)Classes are taught in other tongue, with little use of the target language actively (2)vocabularies are taught in the form of isolated words (3)longer explanation is given for the grammar (4)grammar provides the rules for putting words together, and instruction often focuses on the form and inflection of words (5)reading difficult text is begun early (6)little attention is paid to the content of texts, which are treated as exercises in grammar analysis (7)often the only drills are exercises in translating disconnected sentences from the target language into the mother tongue (8)little or no attention is given to pronounciation, and (9)the focus is on accuracy, and not fluency. The activity in teaching using GTM is a combination of learning grammar and translation. By learning using GTM, it makes students understand the sentence easily because the communication in learning uses target language that translated in the mother tongue.

However, nowadays, curriculum in Indonesia demands a holistic learning because it is very important for teachers to implement an integrated language curriculum that highlights the relationship between the languages. Holistic approach can potentially develop learner's language awareness (Elorza\&Muňoa, 2008; Cenoz\&Gorter, 2011). It is related to how native speakers learn their own language. Native speakers learn English without learning the pattern, but they were born with English, not one they have learned. A method which adopted native speaker's way to learn English called discovery learning. Bruner explained discovery learning in the following 
way: "Discovery teaching generally involves not so much the process of leading students to discover what is 'out there', but rather, their discovering what is in their own heads." (Bruner, 1971, p. 72; Takaya, 2008). This method helps students learning English through context. Therefore, students learn English constructively. The students are asked to find the characteristics of Tenses and how it can be used by text given by the teacher.

Tenses are not finished yet. No one method is proven effective for some extent. There are some benefits of grammar translation method which suitable for Indonesia students (Hermita \& Suyudi, 2009). First, exploiting one of the skills in teaching English that is reading. According to (Dallman, et.al, 1982:22). It means that reading is a verbal process which has a relation with other language skills namely, listening, speaking and writing, and reading is the process of reconstructing information from the author to the reader. Second, it encourages students to learn how to communicate in a foreign language and read and appreciate foreign language literature. It talks about grammar rules and vocabulary in the target language. The last, the ability to communicate in target language is not the goal of foreign language instruction in Grammar-Translation Method, so that Indonesian students can learn English easier because English is foreign language not second language in Indonesia.

Furthermore, a contrastive study between grammar translation method and recent generate proposal namely discovery learning is an interesting topic to explore. To complete and get the newest finding of the old method and recent method, the researchers decided to conduct a constructive study. Furthermore, the researchers want to know the better method to learn tenses which suitable for Indonesian EFL Students.

\section{LITERATURE REVIEW}

\section{Grammar Translation Method}

Grammar Translation Method is one method that focuses on the translation from one language into another language and learning the rule of grammar. According to Celce-Murcia (2001), Grammar- Translation approach is an extension of the approach used to teach classical language to the teaching of modern languages. This method is called a Classical method since it was firstly used in teaching language. Furthermore, in teaching using Grammar Translation Method, it begins with rules of grammar, isolated vocabulary items, then translation from one language to another language. Moreover, pronunciation is limited to be taught and grammar rules are memorized with giving the sentence illustrations. According to Jack Richards (2006;6), there are some principles as the characteristic of the Grammar Translation Method:

1) The goal of foreign is to learn a language in order to read its literature or in order to get benefit from the mental discipline and intellectual development as the result of foreign language study.
2) Reading and writing are the major focus, little or no systematic attention is paid to speaking or listening.

3) Vocabulary selection is based on the reading texts used, and words are taught through the bilingual word list, dictionary study and memorization.

4) The sentence is the basic unit of teaching and language practice.

5) Accuracy is emphasized.

6) Grammar is taught deductively that is, presentation and study of grammar rules, which are then practiced through translation exercises.

7) The student's native language is the medium of instruction. It is used to explain new items and to enable comparison to be made between the foreign language and student's native language.

However, teaching using Grammar Translation Method cannot develop the competence of communicative interaction for students. Students are good at memorizing rules and translating the text, but they are lack in communicating with English. By using this method, teachers are taught the language using mother tongue and the use of target language becomes less active.

\section{Discovery Learning}

Discovery learning is one of teaching and learning methods which is based on the contextual phenomenon. Bruner (1961) stated that learning happens by discovering, which prioritizes reflection, thinking, experimenting, and exploring. Those activities are effective to help students to learn about somewhat. Through discovery learning, students are required to think in higher order thinking skill, be brave to do the experiment and explore the study. Discovery is a way from the unknown to the known by the learners themselves (Bruner, 1966). It changes students' perspective about the difficulty of the material because the students learn by themselves.

Bruner explained that discovery learning in the following way: "Generally,Discovery teaching involves not so much the process of leading students to discover what is 'out there', but rather, discovering what is in their own heads". (Bruner, 1971, p. 72; Takaya, 2008). In discovery learning, the students are allowed to analyse, find the characteristic or pattern and explore more the material which makes students get deeper understanding because they have experienced it by themselves. Learners' active participation in learning process is called discovery learning (Bruner, 1968; Kara \&Özgün-Koca, 2004; Kipnis, 2005). When the students are being active in the learning process, they will contribute step by step and it can call as discovery learning because the students discover the materials by themselves. In discovery learning, students construct knowledge based on new information and data collected by them in an explorative learning environment (De Jong \& Van Joolingen, 1998; Njoo, 1994). 


\section{METHOD}

This article employed library research. It means that this research used literature sources, such as books, notes, and reports on research result from previous study. Library research is that used library sources to get and analyze the data (Zeid, 2004:4). On another side, library research is a form of structured inquiry with specific tools, rules, and techniques (George, 2008:1).

The data were identified from discourse of books, papers or articles, magazines, journals, web or internet, or other information related to this research. According to Glasser and Strausss (1967:176), the data of library research is not limited by time and space. The source of the data in the research is object from which the data can be obtained (Arikunto, 2010;129). The data are analyzed to answer the research question. After collecting the data, they were analyzed through the following procedure; Reading, Classifying, Analyzing, and making a conclusion.

\section{FINDINGS AND DISCUSSION}

\section{The Characteristics of Grammar Translation Method and Discovery learning in teaching Tenses.}

There are some different aspects that contrasting between Grammar Translation Method and Discovery Learning. First, the use of mother tongue in teaching and learning process. In Grammar Translation Method, the teacher teaches the target language using mother tongue. The teacher is facilitating students by using native language in the teaching learning process. According to Harmer $(2007 ; 63)$ said that in the teaching learning process, the students were given the explanation and the sentences that had to be translated from first language to the target language and vice versa. Second, in teaching tenses using Grammar Translation Method, the teacher gave the explanation then the explanation is followed by sample sentences by students to know how far they understood about the material. According to Learsen (2000:18) explain that the teacher teaches the grammatical rules by giving the example first then ask the students to memorize itand ask to apply and make another example. Furthermore, based on the finding of research conduct by Arifin (2016) found that deductive method is more effective in teaching tenses because the teacher gives the rules, the concept, and the function of tenses explicitly so the students can get a clear explanation about the materials.In comparison, teaching tenses in the class through Discovery learning, the teacher used the target language in the classroom. The teacher start giving an example in which the rules are inferred or concluded by the teacher. There is no need to memorize the rules and patterns of the tenses. Based on Brown and Thornbury(2002:13) explain that the use of Discovery Learning in teaching Tenses is good for some reasons such as help learners to learn about grammar unwittingly. It means they do not have to understand the concept of grammar, they can explore the concept by themselves so they will become autonomous learners. Learning about grammar also becomes more meaningful and allow the students to be more active in the teaching learning process. Moreover, this approach invents the situation and giving examples where students should find by themselves or the teacher also will help them (Mohammed \&Jaber, 2008, p.546).

\section{The Goals of The Method}

Grammar Translation Method is aimed to ease the students to understand the study by analysing the language. CelceMurcia (2001:6) Grammar Translation Method gets the students to analyse the language rather than to use the language. Freeman stated that Grammar Translation Method is used to help students read and appreciation foreign language literature. From those purposes, it is hoped that Grammar Translation Method helps students become more familiar with grammar from native language and improve speaking and writing skills. In contrast, Discovery learning is a method which is very beneficial for students to do independent study because it makes the students observe and answer some questions by themselves. Hammer (1997:489) explained that Discovery learning aims to prepare the students to expose particular questions and give them experiences in such a way that they "discover" for themselves the intended concepts. According to Holesisnska (2006:1) cited in Rahmi\&Ratmanida (2014), the students will be involved with words and it is likely to help them to learn and remember them. It means that Discovery Learning makes the students to become curious with the study so that they will get more information, also stimulates them for being more creative and confident. Some of those purposes have been proved by Castronova (2002) cited in Suphi\&Yaratan (2016) that discovery learning invests curiosity and motivation to analyse a study and make sense of the information what they encounter. Discovery learning helps the students to be more active in the teaching and learning process, gives new experiences and eases the students to learn by using technology, and improve the students' writing skill from low creativity to high creativity (Prawerti, 2014). Sound and Sense-Abilities (2004) cited in Emily Brown (2006) argued that Discovery learning makes the classrooms to be more inclusive, prospective and active. Teachers need to apply strategies that assure the full participation of students with disabilities as classrooms are becoming more diverse ethnically and developmentally.

\section{The Role of The Teacher}

From those two methods, the teacher has different role in each method. In Grammar Translation Method, teacher is a centre of teaching and learning process in the classroom. Erlam (2003) in Syaadiah (2016) argued that the teacher give instruction and develop the teaching materials, pre-test, posttest, and delayed post-test. In the classroom, teacher presents the language structure so the teacher will dominate in the process. The teacher presents the rules and organizes the practice. Conversely, in Discovery Learning students are the centre of the teaching and learning process. The teacher provides the language that the learners need to discover the rules but it does 
not mean the students get the content of the lesson directly in the beginning and opportunities to practice, guides them in discovery if necessary and the teacher must master the techniques in providing stimulus.

\section{The Nature Interaction}

\section{Teacher-student interaction}

According to Harmer (2007:63), in Grammar Translation Method most of tye activities in teaching learning process are coming from the teacher. On the other hand, in this method the teacher demonstrates the material in one way, teacher as the main role in teaching and learning. The students just ask the meaning sentences or questions that they do not understand to the teacher. Then, the teacher will help the students directly by providing its translation. In contrast, Discovery Learning offersactive interaction between the teacher and the student.The teacher regards the student as friend to discuss the lesson. Therefore, the teacher is not only the main role but also as provider or learners' friend to reachto the goal of teaching learning process So, it can be said that Discovery Learning is an interaction from the teacher to student and from the student to the teacher actively (Thompson, 1996. Brown, 2007:47. Hiep, 2005:4)

\section{Student-student interaction}

From the previous study, in Grammar Translation Method there is little interaction between students and mostly they do not have interaction in teaching learning process. As the result, the students do not communicate each other using target language and their knowledge is exclusively from the teacher. In addition, according to Hiep (2005:4),Discovery Learning stressedthe interaction among students and they can also communicate each other to analyze problems or to answer questions that given by the teacher. However, the Discovery Learning versus expository debate continues to a timeless debate on how much the student should help student or himself (Bruner, 1983).

\section{Methodology for Teaching Grammar in Indonesia}

There are several studies which had been done about applying certain methods to get the best result in learning tenses. They were conducted as an effort to help Indonesian students to get better understanding about grammatical form easily. In KTSP 2006, teacher is the centre in learning and teaching process. In this case, Grammatical Translation Method is suitable to use because the main activity in the classroom and learning source just come from textbook and teacher's voice. However, according to Permendikbud (Ministry of Education and Culture Regulation) No. 65 on 2013 about the standard process, to realize the skill which will be taught, learning model which applies the discovery/inquiry learning model is needed (2013:9). It means to increase students' English skills, the appropriate method is discovery learning. The purpose of learning tenses is to comprehend native language both written and spoken. Therefore, discovery learning is the most suitable method for new curriculum in Indonesia as the government's regulation refers to.

\section{CONCLUSION}

Both of Grammar Translation Method and Discovery learning have strengths and weaknesses. Teaching tenses using Grammar Translation Method enables the students to have a clear explanation about the concept, functions, and pattern of the tenses as it has been taught and explained by the teacher. Moreover, teaching the tenses using Grammar Translation Method make the students easy to understand by analysing the language. Meanwhile, teaching using Discovery students enables the students learning through the context. They can explore the material and find it by themselves. The teacher can prepare the students to expose some question and give the new experience from what they have discovered. In another hand, Grammar Translation Method and Discovery Learning have several weaknesses, for example in Grammar Translation Method, the teaching learning process is dominated by teacher's explanation, it will decrease students' interaction, the students also cannot be active in the class, and not all the explanation will be remembered by the students because the teacher explains many things about patterns or rules. While, the implementation of Discovery learning needs much time and also spends more energy for the students because they are the main object in classroom activity (Trika, Ana, \& Ratminingsih, 2012). In addition, English teachers have to implement the discovery learning in teaching tenses. It is in line with the regulation from the Ministry of Education and Culture no 65, 2013 that explain about learning model which should be applied in new curriculum is the discovery/inquiry learning model.

\section{REFERENCES}

[1] Ratmaningsih, I. K. (2012). Teaching English Tenses to EFL Learners : Deductive or=ujp[ Inductive? International Journal for Cross-Disciplinary Subjects in Education (IJCDSE), 998-1004.

[2] Natsir, M. (2014). Grammar Translation Method (GTM) Versus Communicative Language Teaching (CLT); A Review of Literature. International Journal of Education \& Literacy Studies, 58-62.

[3] Arifin, S. (2016). Deductive and Inductive Methods in Teaching Tenses. Journal of ELT Research, 73-89.

[4] Hanafi. (2016). The Effect of Discovery Learning Method Application on Increasing Students' Listening Outcome and Social Attitude . Dinamika ilmu, 291-304.

[5] Richard, Jack C., \& Theodore S. Rodgers. (2001). Approaches and Methods in Language Teaching (2nd Edition). Cambridge: Cambridge University Press.

[6] Thornbury, S., How to Teach Grammar Pearson Education Limited, Malaysia, 2002 p.13 Ur, P., 
[7] Grammar Practice Activities: A Practical Guide for Teacher, Cambridge University Press, Cambridge, 2006.

[8] Mohammed, A. A., \& Jaber, H. A. (2008). The effects of deductive and inductive approaches of teaching on Jordanian University students' use of the active and passive voice in English College Student Journal, 42(2), 545-553.

[9] Trika, I. K., Ana, A., \& Ratminingsih, N. M. (2012). Teaching English Tenses to EFL Learners : Deductive or Inductive ?, 2(2), 998-1004.

[10] Hiep, P.H. (2005). "Imported" Communicative Language Teaching Implication for Local Teacher.Journal o English Forum.43 (4) 2-9. 